\title{
Stimulated By Retinoic Acid Gene 6 Protein Homolog
}

National Cancer Institute

\section{Source}

National Cancer Institute. Stimulated By Retinoic Acid Gene 6 Protein Homolog. NCI

Thesaurus. Code C104695.

Stimulated by retinoic acid gene 6 protein homolog $(667 \mathrm{aa}, \sim 74 \mathrm{kDa})$ is encoded by the human STRA6 gene. This protein is involved in retinoid metabolism. 